\title{
Coping with Global Debt Crises: Debt Settlements, 1820 to 1986
}

\author{
CHRISTIAN SUTER \\ HANSPETER STAMM
}

University of Zurich

The settlement of the external debt of insolvent sovereign borrowers has become one of the most important issues in relations between the north and south since the outbreak of the global debt crisis in the early 1980s. For the past eight years representatives of governments and international organizations, bankers, and scientists have suggested several proposals and plans to solve the present debt crisis. The most prominent schemes in this respect are the Baker Plan of 1985, which suggested massive new credits for the most highly indebted developing countries, and the recently adopted Brady Plan, which proposes partial debt discounts and reductions in interest rates. Both of these debt settlement proposals were initiated by the United States and are supported by the other principal creditor countries. However, despite the ten years of crisis management, world leaders have not yet agreed upon a longterm solution to the current debt problems. In the history of the capitalist world economy, the current problems of coping with a global debt crisis do not represent a unique event. Rather, recent empirical studies demonstrate that sovereign borrowers have experienced many instances of debt-servicing difficulties during the past 150 years (Eichengreen and Portes 1986; White 1986; Eichengreen and Lindert 1989; Marichal 1989; Suter 1989).

In fact, together with the present global debt crisis, four periods of widespread debt-servicing incapacity affecting mainly peripheral or less-developed countries can be discerned since 1800: from the late 1820 s to the early 1840 s, from the mid-1870s to the early $1880 \mathrm{~s}$, from the early 1930 s to the late $1940 \mathrm{~s}$, and since the early $1980 \mathrm{~s}$. During these periods of crisis the number of countries with debt problems amounted to fifteen (late 1820s), seventeen (mid-1870s), twenty-five (early 1930s), and thirty-three (1984). Indeed, the proportion of all the sovereign nation states confronted with debt-servicing

A previous version of this paper was presented at the joint annual convention of the Austrian, German, and Swiss Sociological Associations, Zurich, October 4-7, 1988. Part of research work for this study has been supported by the Swiss National Foundation (grant 1.060-0.84) and the World Society Foundation, Zurich. We would like to thank Ulrich Pfister, Volker Bornschier, and the editors and reviewers of Comparative Studies in Society and History for their helpful suggestions, comments, and criticisms on earlier version of this paper.

0010-4175/92/4405-2533\$5.00 C 1992 Society for Comparative Study of Society and History 
incapacity amounted to 30 percent in the late 1820 s, 37 percent in the mid-1870s, 40 percent in the early 1930s, and 27 percent in 1984 (Suter 1990:306-10).

However, despite those obvious similarities one important difference exists between the present and earlier debt crises: Before World War II, debt crises manifested themselves in outright defaults on foreign governmental bonds, whereas from the 1950s onward defaults have been forestalled by the arrangement of multilateral debt rescheduling agreements. Yet, because the current debt crisis is still far from settled, it would be risky to conclude that the rescheduling strategy is superior to the default strategy previously used. Against the background of this historical evidence one may rather ask exactly how earlier debt crises were finally settled and what can be learned from those experiences for a better understanding of, and an improved coping with, the present difficulties.

A large body of literature explores the historical dimension of debt crises and their solution. These studies examine the long-run experiences of one or a small number of debtor countries on the one hand (see, for example, Landes 1958; Bazant 1968; Thobie 1980; Scheetz 1986; Pamuk 1987; Aggarwal 1989; Cardoso and Dornbusch 1989), as well as the government and private creditor response to debt problems on the other (for example, Kindleberger 1978; Fishlow 1986; Stallings 1987; Lipson 1985, 1989). In addition, debt settlements of specific crises have been studied in some depth (for example, Eichengreen and Portes 1986, 1989; Fishlow 1989). The single most important empirical contribution on debt crises and debt settlements, Marichal's recent study (1989), characterizes them as loan cycles-recurrent stages of loan boom and debt crisis. Yet this analysis is limited in space and time because it is confined to Latin American countries between 1823-1930. ${ }^{1}$ Thus, one has to conclude that there is a lack of studies which examine the above-mentioned crises simultaneously on the aggregate level of the whole world economy. Hence, this analysis attempts to describe and to explain the pattern of debt settlement by comparing the present debt crisis with the three previous principal crises using selected quantitative indicators covering virtually all the cases of settled defaults and agreed reschedulings from 1820 to 1986.

This comparison is done on the basis of four principal dimensions. The first and basic dimension relates to the actor structure underlying the financial relations between creditors and debtor countries and the resulting institutional framework associated with the debt settlement processes. An important ele-

\footnotetext{
1 Marichal's (1989) study does not deal within its spatial and temporal limits with all cases of default and debt settlement. Thus, although the Argentine default of 1891 is described in detail, the defaults of Uruguay (1891), Santo Domingo (1892, 1897, 1899), Venezuela (1892, 1898), Guatemala (1894, 1898), Ecuador (1894), Costa Rica (1895), and El Salvador (1897) were not mentioned.
} 
ment with respect to the actor structure refers to the strength of cooperative arrangements among creditors. The other three dimensions deal with the pattern of debt settlements. The second dimension refers to the efficacy of the crisis management, the third dimension to the degree of economic and political influence exerted on debtor countries by creditors, and the fourth dimension to the terms of the debt settlement, that is, to the degree of debt relief granted by creditors.

Our basic hypothesis suggests that the three dimensions referring to the pattern of debt settlement - the efficacy of the crisis management, the degree of creditors' influence, and the extent of debt relief-are determined by the actor structure or, more specifically, by the actor structure on the creditors' side. Thus, we argue that quick and efficient crisis management, the capability of creditors to exert far-reaching influence on debtor countries and to enforce hard terms of debt settlements against the interests of debtor countries, depends upon the establishment of strong cooperative networks among creditors. The institutionalization of such creditor clubs on their part presupposes that a relatively few actors dominate a dense interaction structure (see Buckley 1967; Voss 1985:203; Pfister and Suter 1987).

Prior to World War II these conditions were not met. Until the debt crisis of the 1930s the principal financial instrument of official external borrowing was the foreign governmental bond, which was generally held by a large number of individual bondholders. In 1914, for example, liabilities of tsarist Russia vis-à-vis France amounting to $\$ 11$ billion were owed to 1.6 million bondholders (Feis 1930:xii). In the post-war period, foreign bonds have been replaced by loans and credits granted by official bodies of creditor countries (such as development assistance agencies), international organizations (such as the World Bank and the International Monetary Fund), and private commercial banks. Development credits (extended either bilaterally by highly developed core countries or multilaterally by international organizations), private and official export creditors, and syndicated credits offered by commercial banks and stabilization loans granted by the International Monetary Fund have become the principal financial instruments. These changes in the dominant financial instruments went together with a marked reduction in the number of actors on the creditors' side, facilitating the formation and institutionalization of strong creditor cooperation.

Cooperative arrangements were already in place before the current debt servicing problems occurred on a large scale. These arrangements could subsequently be used as a starting point for fast action. For example, official lending was confined to the few most developed core countries organized within the Development Assistance Committee (DAC) of the Organization for Economic Cooperation and Development (OECD). With the foundation of the DAC in 1960, official donors set up a joint forum and established cooperative decision-making processes in development assistance. Moreover, official do- 
nors and international organizations promoted further cooperation in development aid by forming aid consortia, consultative groups, and round tables. Commercial banks, largely dependent upon each other owing to the system of interbank credits for their part, provided the large loans which sovereign borrowers needed jointly in the form of so-called syndicated credits.

Our basic hypothesis concerning the relations between actor structure on the one hand, and the efficacy of crisis management, degree of creditors' influence, and extent of debt relief on the other may be developed further by using the concept of world leadership or hegemonic cycles developed by Modelski (1978) and Wallerstein (1983). Basically, world leadership cycles describe the actor structure within the most highly developed core countries which also represent an important segment within the group of creditors. World leadership cycles are characterized by the rise and decline of hegemonic powers within the world-system. Generally, hegemony is based on productivity advantages due to the early introduction of basic technological, social, and organizational innovations. However, as such innovations are adopted by other core countries, the advantages are narrowed and eventually disappear. ${ }^{2}$ When a country rises to hegemonic power, the actor and power structure of the world-system is unicentric and the hegemonic power is capable of shaping the economic and political order of the world system according to its interests. With the decline of a hegemonic power, the actor and power structure within the core becomes multicentric. World leadership cycles also affect the relationships between core and periphery, that is, between creditor and debtor countries. Among others, Chase-Dunn (1989:273) argues that the hegemony of a single core country leads to a more multilaterally structured core-periphery relationship and a relaxation of political forms of core control over the periphery. Conversely, core countries tend to tighten their bilateral relations with peripheries and to resort to political forms of control when the world-system becomes structured in a multicentric fashion. The nineteenth and twentieth centuries were dominated by two hegemonic powers: During the nineteenth century, British supremacy prevailed, whereas between the turn of the century and World War II the power structure became multicentric. During the postwar period the United States first gained the hegemonic position which, however, has begun to deteriorate from the 1970s onwards.

From the above reasoning one may draw the following sub-hypotheses concerning the pattern of debt settlements. First, one may argue that debt crises are more quickly negotiated during hegemonic phases, when the world system is economically and politically dominated by a single world power which is interested in the maintenance of financial stability and may act as a

2 In addition to the economic forces emphasized by Wallerstein (1983) and Chase-Dunn (1989), political and military processes are also relevant (see, among others, Modelsky 1978 and Kennedy 1987). 
kind of an international lender of last resort. Second, the economic and political influence exerted on debtor countries by creditors is expected to be more pronounced when the power structure becomes multicentric due to the rising competition among core countries. Third, the terms of debt settlements may be more favorable for debtor countries in phases of uncontended hegemony because the hegemonic power, unlike competing core countries, disposes of the necessary financial resources. Conversely, the existence of several leading powers improves the bargaining position of individual debtor countries at the periphery. Therefore, the situation most favorable for debtors is during the transition phase from an old and decaying hegemonic power (which is, however, still one of the most important creditor countries) to a new and rising world leading power trying to integrate debtor countries at the periphery into its own and newly emerging power system at the expense of the old hegemonic power. In addition, one may expect differences in the settlement pattern between different hegemonic powers, as between Britain and the United States. Thus, Lipson's (1985, 1989) comparison of security policies concerning foreign capital between Victorian Britain and postwar America suggests more interventionist policies during the hegemony of the United States.

According to our discussion of the structural differences between the three debt crises of the late 1820s, the mid-1870s and the early 1930s on the one hand and the current debt-servicing problems of sovereign borrowers on the other, we first deal with the settlement of defaults on foreign governmental bonds prevalent prior to World War II. Thus, the next section provides a comparison of debt settlements concluded in connection with the three earlier crises concerning the four dimensions elaborated above (actor structure and institutional framework, efficacy of crises management, degree of creditors' influence and extent of debt relief). Section II subsequently analyzes the settlement of debt-servicing incapacities during the post-war period, that is the pattern of multilateral reschedulings of official and private credits. Section III summarizes the differences between the settlement of defaulted foreign bonds and multilateral reschedulings. Finally, section IV discusses the various debt proposals initiated during the past decade in the light of the historical experience and draws some conclusions regarding the prospects for future debt settlement strategies.

\section{THE SETTLEMENT OF DEFAULTS ON FOREIGN GOVERNMENTAL BONDS: DEBT CRISIS MANAGEMENT PRIOR TO WORLD WAR II}

Before World War II the negotiation and settlement of defaults on governmental bonds was rather weakly institutionalized, especially so during the first three quarters of the nineteenth century. With their unilateral suspension of interest or amortization payments, defaulting countries violated the provisions of the loan agreements. A debt settlement thus implied a formal renegotiation 
of this contract between the debtor country and its bondholders. Such arrangements, however, were rather difficult to realize, as the negotiation process was complicated by the dispersion of creditors within a large mass of small bondholders.

During the nineteenth century, bondholders were only badly organized. When default occurred, bondholders tried to establish committees in order to protect their interests and to enter into negotiations with representatives of the defaulting country. The mere formation of such ad hoc committees was, however, rather time-consuming. Moreover, these committees usually had only limited competence. Thus they could not conclude binding agreements with the respective debtor country. Rather, the arrangements concluded by the committees had to be approved by a general meeting of the bondholders concerned. But even if the majority of bondholders accepted the arrangement, it was not binding on the individual bondholders. In addition, the committees lacked the necessary financial resources, infrastructure, and access to information on the economic and political situation of the respective debtor country. The rivalry between several competing committees often further weakened the bargaining power of bondholders' representatives. ${ }^{3}$

As a reaction to these problems of creditor coordination and cooperation, permanent central national bodies were established in most important creditor countries from the late nineteenth century onwards. The first and most important of these national protective committees emerged in Great Britain, when the Council of the Corporation of Foreign Bondholders was formed in 1868. Similar bodies were established in other creditor countries, such as France and Belgium (1898), Switzerland (1912), Germany (1927) and the United States (CFB 1933; see Winkler 1933:153-78; Borchardt 1951:214; Eichengreen and Portes 1989:15-25). These central councils established committees to protect bondholders' interests when a default occurred, nominating the members of the committee and usually organizing a general meeting of bondholders to ratify their appointments. Permanent committees were established for countries with a bad debt record. The national bodies supported the committees with infrastructure (e.g., offices, secretary services), financial resources (e.g., travel expenses) and technical advice. The committees entered into negotiations with the defaulting country and worked out an agreement with the respective debtor country for a settlement of defaulted debts. The national council then recommended that the bondholders accept this agreement, which was, however, as noted above, not binding for the individual bondholders.

Two further forms of debt adjustment can be discerned in addition to the negotiation of such formal agreements between bondholders' committees and defaulting countries. First, in the case of temporary suspensions or defaults on

3 In the wake of the Portuguese default of 1892 , for example, three different bondholders' committees were established in France alone (Union des Porteurs Français de Rentes Portugaises $1893: 21$ ). 
amortization payments alone, bondholders' claims were in general simply met by a repayment of arrears. Second, existing obligations were sometimes converted into new debts by a concerted action of creditors before the debtor country was forced into open default. Yet such consolidations, which are rather similar to the multilateral rescheduling technique of the post-war period, could be realized in only four cases. ${ }^{4}$

We now turn to a closer inspection of the pattern of debt settlements concerning defaulted foreign governmental bonds. From 1820 to 1975 some 120 debt settlements were concluded between bondholders' committees and debtor countries. ${ }^{5}$ These settlements mainly relate to defaults on interest payments or on both interest and amortization payments; amortization payments alone were adjusted in only five cases. The principal sources for the following empirical analysis are the annual reports of the British Council of Foreign Bondholders from 1873 to 1985 , which contain a detailed record of the negotiation processes and the terms of the settlements agreed upon between bondholders and debtor countries. In addition, the annual reports of the French and Belgian bondholders' associations and the weekly issues of The Economist (from 1843 until 1939) were used (see Association Française, Association Belge, Corporation of Foreign Bondholders [CFB]). ${ }^{6}$

As outlined in the preceding section, the pattern of debt settlement is examined for the efficacy of the crisis management, the degree of economic and political control exercised by creditors over debtor countries, and the degree of debt relief granted by creditors. These three dimensions, which are supposed to be closely associated with the actor structure and the strength of cooperative arrangements among creditors, will be analyzed separately for the settlement of each of the three major debt crises. As demonstrated by the empirical material presented by Marichal (1989) for Latin America and by Suter (1989:26) for the whole world economy, the three crises culminated in $1828-40$, in 1876-81, and in $1932-45 . .^{7}$ Debt settlements were usually reached several years after the outbreak of debt crises. Thus, peak years in the number of debt settlements concluded were the 1840s, the 1890s and the decade after World War II. For the following empirical analysis the three periods of default settlements defined are delimited by the trough years of the three principal debt crises. The number of sovereign borrowers in default was

4 These instances are Colombia (1873), Serbia (1895), Morocco (1903-04), and Liberia (1912); a consolidation was reached in the case of the Argentine debt crisis of 1890 a few months after the suspension (Suter 1990: Appendix A).

5 This figure relates to final agreements only. Temporary arrangements and agreements which did not become effective have been excluded.

6 The annual reports of the British bondholders are hereafter referred to as CFB. For a more detailed description of the data set and the sources, see Suter (1990).

7 Several Latin American debtor countries also experienced serious debt servicing difficulties in the wake of the Baring crisis during the early 1890s (see Fishlow 1989 and Marichal 1989:149_ 70 for the Argentine case). Another small debt crisis occurred during World War I and affected debtors like Bulgaria, Liberia, Mexico, the Ottoman Empire and Russia (Suter 1990:283). 
lowest in 1871 (five countries) and in 1926-27 (three countries) while the number of reschedulings started to rise from 1975-76 onwards (see Suter 1990:306-10). Hence, the first default settlement period covers 1821-70; the second, 1871-1925; and the third, 1926-75.

In general, each of the three periods defined above begins with a wave of defaults characterizing the outbreak of a global debt crisis (late 1820s, mid-1870s, early 1930s) and comes to an end when all defaults have been settled by arrangements between the defaulting countries and bondholders' representatives. This conception presupposes that the default-settlement sequences of the three principal debt crises are not overlapping: that each default is settled before the next principal debt crisis emerges. Yet, as mentioned above, five sovereign borrowers which had suspended payments in the wake of the first global debt crisis were still in default when the crisis of the mid-1870s broke out. Similarly, three defaulting countries of the second default-settlement period reached a debt settlement only after the outbreak of the crisis of the 1930s. Because we are interested in comparing the settlement strategies of the three principal periods of debt crises, these eight cases cannot be classified clearly into one of the three default-settlement periods and could thus distort the pure configuration of the crisis-specific settlement patterns. Thus, they have been excluded in the following empirical examination.

\section{Efficacy of Crisis Management}

The efficacy of managing a debt crisis involves two related aspects: the capability to take action and to respond quickly to a looming crisis on the one hand and the durability of the crisis solution on the other. Consequently, efficient strategies of the crisis management are characterized by a quickly reached and long-lasting debt settlement. As a measure for the quickness of the crisis management, the duration of defaults, such as the time span between the outbreak of debt service incapacities and the final conclusion of the debt settlement arrangement, has been computed. The figures presented in Table 1 for 114 debt settlements for which data are available show an average duration of defaults on foreign bonds of nine years, that is, an average of nine years passed after default before debtor countries reached a final settlement with their creditors (see Table 1). ${ }^{8}$ Our empirical evidence suggests that bond defaults were not at all rapidly followed by settlements as claimed by Jorgensen and Sachs (1989:49) and that the efficacy of crisis management was rather poor. This has to be attributed to the bondholders' low level of institutionalization. As discussed above, merely organizing the bondholders was rather time-consuming. Even after the permanent national protective councils were established, the bondholders' committees lacked the competence to ar-

8 The average default duration rises to ten years when those eight cases which were not classified into one of the three default-settlement periods are included in the calculation. 
TABLE 1

Average Yearly Duration of Defaults on Foreign Governmental Bonds and Durability of Debt Settlements ${ }^{a}$

\begin{tabular}{lcc}
\hline Default-Settlement Period & $\begin{array}{c}\text { Duration of Defaults } \\
\text { (in Years) }\end{array}$ & $\begin{array}{c}\text { Durability of Settlements } \\
\text { (in Years) }\end{array}$ \\
\hline 1. $1821-1870$ & $14.0(25)$ & $18.6(24)$ \\
2. $1871-1925$ & $6.3(52)$ & $21.2(49)$ \\
3. $1926-1975$ & $10.1(37)$ & $23.7(31)$ \\
Total: $1821-1975$ & $9.2(114)$ & $21.4(104)$ \\
\hline
\end{tabular}

${ }^{a}$ The number of cases is indicated in parentheses.

SOURCES: Corporation of Foreign Bondholders (Annual Reports 1873-1985); Pfister and Suter (1986); Suter (1990).

range binding agreements with debtor countries, making the negotiation process difficult and lengthy. Thus, one has to conclude that the gradual institutionalization of bondholders' interests into permanent protective councils had little impact on the efficacy of crisis management.

In addition, there are some differences between the individual defaultsettlement periods. Thus, the duration of defaults was highest during the period 1821-70 (fourteen years) ${ }^{9}$ and lowest in 1871-1925 (six years). A one-way analysis of variance with the duration of defaults and the settlement period as the dependent and independent classification variables, respectively, shows substantial differences in group means of settlement periods. ${ }^{10}$ In order to compute the contrasts between individual group means, Scheffé's test has been computed. It shows significant differences only between the periods $1821-70$ and $1871-1925.11$ Because the variance within groups is rather high, ${ }^{12}$ the differences between the three default-settlement periods should be interpreted with caution. Moreover, one has to take into account that our data cover only defaults that were eventually settled. Nevertheless, the following comments which can be derived from the hypotheses discussed in the introductory section should be made.

First, the extremely long duration of defaults during the first settlement

9 This figure is somewhat lower than Marichal's estimation of fifteen to thirty years for the duration of defaults by Latin American countries during this period (1989:60). These differences may be attributed to the more prompt settlement negotiated by the non-Latin American defaulting countries (for example, Spain or the United States, which also were the most important debtors of those days) indicating the greater relevance of the European periphery and the United States for the international financial system of the early nineteenth century.

${ }^{10} \mathrm{~F}$-value for one-way analysis of variance is 6.4 (level of significance is .01).

11 Scheffé's test is the most conservative test for a posteriori contrasts.

12 The model explains only 10 percent of total variance. 
period (1821-70) may be attributed to the lack of permanent bondholder committees. Furthermore, most debtor countries in default during the debt crisis of the late 1820s suffered from heavy political instability and a weak state apparatus with a narrow financial resource base. This holds especially for Greece and several Latin American debtor countries which had just become independent.

Second, the comparatively quick settlement of defaulted bonds during the period 1871-1925 is more difficult to explain. One may argue, first, that in contrast to the deep and protracted crisis of the 1930s, the depression of the world economy during the 1870 s was quickly overcome. The rapid expansion of the world economy during the 1880 s and the first decade of the twentieth century may have accelerated the settlement processes considerably. A second line of reasoning refers to the concept of world leadership cycles. As expected, the defaults occurring in the wake of the debt crisis of the mid-1870s, when Britain had an uncontested financial supremacy, were more quickly settled than the defaults of the 1930s, when different powers in the core of the world system were contending for supremacy. ${ }^{13}$

Third, the argument that core rivalry can explain the relatively long duration of defaults in the wake of the crisis of the 1930s should be elaborated further: It may be expected that the rivalry between the two military superpowers, the United States and the Union of Soviet Socialist Republics (USSR), and their political allies that emerged after World War II and culminated in the Cold War delayed the debt settlement process in cases of debtor and creditor countries not belonging to the same political alliance. In fact, most Communist governments repudiated the foreign bonds raised by their predecessors from Western core countries. During the 1950s and 1960s four Communist countries (Poland, Romania, Hungary, and Yugoslavia) eventually concluded a debt settlement with creditors. The average duration of these defaults amounted to twenty-one years, more than twice the average of the default-settlement period 1926-75. Moreover, five Communist countries (Bulgaria, China, German Democratic Republic, Czechoslovakia, USSR) were still in default by 1975 .

The duration of defaults is, however, only one aspect of the crisis management. Another important dimension of the efficiency of the debt crisis management refers, of course, to the quality of the solution, which in a broad sense may be defined as the durability of a debt settlement. Due to the quantitative nature of our data the measurement of this aspect can only be approximate. The time period between the conclusion of the debt settlement and the outbreak of the next debt service incapacities (default or rescheduling)

13 Similarly, Kindleberger $(1973,1978)$ explains the severeness of the crisis in the 1930s with the lack of a hegemonic power that felt responsible for the stability of the international financial system. He argues that Britain was not able to act as a lender of last resort and the United States were not willing to do so. 
has been calculated as the indicator of the durability of the crisis management. As shown in Table 1, the average durability of debt settlements for 104 cases is twenty-one years. ${ }^{14}$ Thus, on the average, after a debt settlement, twentyone years elapse before the same country defaults once again or negotiates a rescheduling arrangement. Between the three default-settlement periods there are no substantial differences in the durability of the crisis management. This substantiates the relevance of the differences in the duration of defaults. Thus, one may conclude that the crisis management during the period 1871-1925 was most efficient, as the durability of debt settlements was similar but average default duration substantially lower than during the periods $1821-70$ and 1926-1975.

\section{Creditor Pressure on Debtor Countries}

Insolvent debtor countries sometimes came under political and economic control of their creditors. The most frequent form of political and economic control was the establishment of debt administration councils and the control of public finance of debtor countries by creditors' representatives. Debtor countries usually had to cede to these councils some financial revenues used to finance interest and amortization payments, such as the state monopolies, taxes and customs duties. In most cases, the council itself collected the revenues assigned. The degree of the creditors' influence on these debt administration councils varied according to the composition of the council. In the case of Serbia (1895), for instance, the council was dominated by representatives of the debtor government, and the influence of bondholders was rather weak (Born 1986). Conversely, the debt administration of Liberia (1912) was largely controlled by creditors and was vested with far-reaching financial competence. Thus, the creditors directly supervised tax and duty collection and reorganized Liberian public finance. As a consequence, the Liberian government completely lost its financial autonomy (Radke and Sauer 1980). Between 1821 and 1975 creditors used political and economic intervention through the formation of debt administration councils in only nine cases - the equivalent to 8 percent of all debt settlements. Most of these cases (seven out of nine) fall into the settlement period 1871-1925.15

In addition to the establishment of debt administration councils by bondholders and creditor countries, creditor countries in two instances also used

14 Ten cases which did not encounter any debt service difficulties after concluding a debt settlement were excluded from calculation.

15 The following debtor countries were subject of the establishment of debt administration councils: Tunisia (1869-70, joint debt administration), Egypt (1876, British-French debt administration), the Ottoman Empire (1881, debt administration by Britain, Holland, France, Italy, and Austria-Hungary), Serbia (1895, joint debt administration), Greece (1898, international debt administration by Britain, France, Germany, Italy, Austria-Hungary, and Russia), Morocco (1903-04, customs administration by France), the Dominican Republic (1904-08 and 1931 customs administration by the United States), and Liberia (1912, debt administration under the direction of the United States with Britain, France, and Germany; see also CFB, Annual Reports). 
open military intervention against defaulting debtors which refused to pay their debt service obligations. In one case France invaded Mexico, against the republican regime of Benito Juárez, with the initial support of Spain and Britain. In 1863 France installed the Austrian archduke, Maximilian, a brother of the Austrian emperor, Franz Joseph, as emperor of Mexico. In the second case, Germany, England, and Italy jointly blockaded Venezuelan ports in 1902-03 because the Venezuelan government under Cipriano Castro did not resume debt service payments after the termination of the civil war. Venezuela also refused to pay any indemnities for war damages to foreign property. After the French intervention against Mexico proved rather unsuccessful, ${ }^{16}$ the claims of the European powers were largely met in the settlement with Venezuela (see Lipson 1989:202-4; Suter 1990:Appendix A). This pattern of very limited political control exerted by creditor countries is in accordance with Lipson's conclusions (1989), from his case studies of the Ottoman Empire, Greece, and Venezuela and his analysis of British diplomacy during the nineteenth century, that the British government exerted little influence on foreign debtors and only rarely used interventionist policies to secure private bondholders' interests.

Apart from such political pressures, debt settlements sometimes also included elements of exclusive economic control. Thus, in nine debt arrangements, debtor countries ceded property rights to creditors. In most cases either land or railways were assigned to bondholders in return for a partial liquidation of existing debts. A telling example is the Peruvian debt settlement of 1889 , which became known as the Grace contract. In this arrangement outstanding debts of some $\$ 30$ million and arrears of interest of $\$ 23$ million were cancelled in return for the assignment of the state railways for sixty-six years, two million tons of guano, and the concession for the operation of steamboats on Titicaca Lake (CFB, Annual Reports 1877-89). Other debtor countries ceding some property rights to bondholders were Colombia (1861 and 1873, land), Costa Rica (1885, railways), the Dominican Republic (1893, railways), Ecuador (1885, land; 1897-98, railways), El Salvador (1899, railways), and Paraguay (1855, land; cf. CFB Annual Reports 1873-1900/1901; Suter 1990:Appendix A). This record shows that seven out of nine cases occurred during the settlement period 1871-1925. Our results demonstrate that purely economic control by creditors is as important as the better known political one. Surprisingly, most studies on creditors' intervention in the wake of bond default only rarely discuss economic control (see Lipson 1985, 1989; Marichal 1989).

One may say in summary that the creditors' political and economic control over debtor countries was rare: It can be demonstrated for only 20 out of 113

\footnotetext{
16 Maximilian was dethroned and executed in 1867 and the Mexican government never paid back the so-called Maximilian debts of some $£ 20$ million (see also Agarawal 1989:143-5).
} 
debt settlements. Yet, most of these cases (15 of the 20) occurred during the settlement period 1871-1925. Four fall into the period 1821-70 and only one into the period 1926-1975. ${ }^{17}$ This pattern suggests that political and economic pressures by bondholders and creditor countries can be interpreted against the background of the rising rivalry among core countries towards the end of the nineteenth century and the resulting imperialist policies pursued by the European powers and the United States. Political and economic control in the context of debt settlements were part of this strategy. This is demonstrated by the cases of Tunisia, Egypt, and the Dominican Republic, which were integrated into the colonial and quasicolonial empires of their principal creditor countries in the wake of payment difficulties.

\section{Degree of Debt Relief Granted by Creditors}

Three dimensions of debt relief have been selected for examination: reduction in arrears of interest, such as the capitalization or conversion rate of arrears of interest into new debts; reduction of interest rates; and reduction in the face value of outstanding foreign bonds. ${ }^{18}$ First, because defaults lasted more than nine years on the average, settling the arrears in interest is the most important dimension of debt relief. Thus, by the time a settlement was finally reached, these arrears in interest often exceeded the face value of defaulted bonds. Usually, the arrears in interest were converted into new bonds at a certain discount, and the interest rates of these new debts were considerably lower than those of the original bonds. Only in the case of the forced Mexican debt settlement of 1864 were the arrears converted at a substantial premium for bondholders. ${ }^{19}$

Table 2 shows the average conversion rate of arrears in interest for the fiftyfour debt settlements for which data are available. From 1821 to 1975 the arrears were converted at a rate of 67 percent into new bonds. Hence, bondholders wrote off an average 33 percent of arrears, and real debt relief was even higher, as compound interest was not considered. During the three default-settlement periods the conversion rate fell continuously from 81 to 35

17 See also Lindert (1989:237) and Eichengreen and Portes (1989:18-20) for an account of government pressures by creditor countries following the crisis of the 1930s

18 A fourth dimension of debt relief which cannot be analyzed due to the lack of data refers to the reduction in amortization rates. Yet, because amortization rates of foreign bonds usually are rather low, they are only of secondary importance concerning the degree of debt relief. A further dimension on which systematic data are also lacking are direct buy-backs on capital markets by debtors. Jorgensen and Sachs (1989) estimated the amount of such buy-backs by Latin American defaulters at 5 to 30 percent of total debts during the crisis of the 1930s.

19 This debt settlement was concluded after France installed Austrian archduke Maximilian as the emperor of Mexico. The arrangement included the conversion of arrears of interest of $£ 2.9$ million into new debts of $£ 4.9$ million. In addition, France supported the regime with a new 6 percent bond of $£ 12.4$ million, of which Maximilian had to pay $£ 4$ million to the French government as indemnification for the French military expedition (CFB 1877:59, 1930:260; Wynne 1951:27ff.; Bazant 1968:93ff. ). 
TABLE 2

Average Degree of Debt Release Granted by Creditors ${ }^{a}$

\begin{tabular}{lccc}
\hline \hline $\begin{array}{c}\text { Settlement } \\
\text { Period }\end{array}$ & $\begin{array}{c}\text { Capitalization } \\
\text { Rate of Arrears } \\
\text { Percentage) }^{b}\end{array}$ & $\begin{array}{c}\text { Reduction in } \\
\text { Interest Rates } \\
\text { (Percentage) }^{c}\end{array}$ & $\begin{array}{c}\text { Reduction in } \\
\text { Outstanding } \\
\text { Debts } \\
\text { (Percentage) }^{d}\end{array}$ \\
\hline 1. $1821-1870$ & $80.7(18)$ & $15.4(17)$ & $2.6(20)$ \\
2. $1871-1925$ & $71.6(24)$ & $16.3(36)$ & $22.8(38)$ \\
3. $1926-1975$ & $35.2(12)$ & $34.5(26)$ & $23.2(23)$ \\
Total: $1821-1975$ & $66.5(54)$ & $22.1(79)$ & $17.9(81)$ \\
\hline \hline
\end{tabular}

"This is based on the capitalization rate of arrears, the percentage reduction in interest rates and in outstanding debts, with the number of the agreements in the parentheses.

${ }^{b}$ The capitalization rate of arrears reflects the average conversion rate of accumulated arrears of interest into new bonds.

"The reduction in interest rates reflects the average reduction in new interest rates as a percentage of the original rates of interest.

${ }^{d}$ The reduction in outstanding debts is the average percentage reduction in the face value of outstanding bonds.

SOURCES: Corporation of Foreign Bondholders (Annual Reports 1873-1985); Suter (1990:23882 ).

percent. Thus, in the wake of the debt crisis of the 1930 s roughly two-thirds of arrears were cancelled. 20

Second, the settlement of defaulted debt also included a renegotiation of interest rates. We have been able to compute the average reduction of interest rates as a percentage of the original rates for seventy-nine debt settlements. As shown in Table 2 , interest rates were lowered by 22 percent on the average. If one also takes into account the considerable reduction in interest rates on converted arrears, the interest reductions were even more substantial. The reduction of interest rates, relatively modest during the periods of 1821-70 and 1871-1925, became more substantial from 1926 to $1975 .{ }^{21}$ Third, debtor countries and bondholders' representatives converted defaulted bonds into new debts in most settlements. As a result of such conversions the amount of

20 In order to test the significance of the differences concerning group means of settlement periods, a one-way analysis of variance with the conversion rate of arrears as dependent variable and the settlement period as independent variable has been carried out. Differences with regard to the group means of default-settlement periods attain a level of significance of .05 ( $F$-value $=$ 5.0). Scheffé's test shows significant differences at the .05 level between the periods $1821-70$ and 1871-1925 on the one hand and 1926-75 on the other.

21 In a one-way analysis of variance these differences between default-settlement periods attain a level of significance of $.001(F$-value $=8.0)$. Scheffé's test shows significant contrasts at the .01 level between the periods $1821-70$ and $1871-1925$ on the one hand and the period 192675 on the other. 
outstanding debt was newly fixed. Table 2 presents the average percentage reduction in the face value of foreign bonds for the eighty-one settlements for which data are available. On the average, outstanding debts were lowered by 18 percent. Although the face value of foreign bonds remained virtually unchanged during the settlement period $1821-70$, it was lowered substantially in 1871-1925 and 1926-75.22

The comparatively high degree of debt release during the settlement period 1871-1925 has to be attributed partly to debt liquidations that the creditors granted in return for political and economic control. As discussed above, several debtor countries ceded land and railways to bondholders in exchange for debt release. If the settlements containing any form of political and economic control are excluded from calculation, reduction of outstanding debts decreases to 12 percent for the period 1871-1925, but the figures remain virtually unchanged for the periods 1821-70 (2 percent) and 1926-75 (24 percent). Despite these elements of political and economic control, creditors granted considerably more debt relief in the wake of the debt crisis of the 1870s than during the first half of the century. In this respect, Marichal's (1989:125) conclusion that defaulting Latin American countries of the 1870s were often forced to pay exorbitant prices for their debt settlements has to be qualified.

When all three dimensions of debt relief are considered together, a trend towards more favorable terms for debtor countries may thus be discerned. The degree of debt relief was lowest during the settlement period 1821-70 and highest during the period 1926-1975. As discussed above, the higher degree of debt relief during the period 1871-1925, compared to the period 1821-70, may be attributed partly to debt liquidations as a result of rising political and economic control of debtor countries by creditors. The comparatively high degree of debt relief during the settlement period 1926-75 may be explained by the dynamic of world leadership cycles, as hypothesized in the introductory section of this essay. Thus, the settlement of defaults after the crisis of the 1930s coincided with the transition of hegemony from Britain to the United States. This situation was rather favorable for debtor countries, as they were mainly indebted to the old and decaying hegemonic power (that is, Britain). The United States as the new world leader did not support British interests but rather tried to integrate debtor countries at the periphery into its own hegemonic power system by granting substantial concessions at the expense of Britain.

To sum up, the pattern of debt settlement with respect to defaulted foreign governmental bonds and its change in the course of the three settlement periods may be characterized as follows. During the first settlement period

22 In a one-way analysis of variance these differences between default-settlement periods attain a level of significance of $.05(F$-value $=3.4)$. Yet Scheffé's test shows no significant differences at the .05 level between individual default-settlement periods. 
(1821-70), foreign bonds remained in default for a relatively long period. The terms of debt settlements were comparatively unfavorable for debtor countries, but the creditors made only a few attempts to control debtor countries politically and economically. During the second settlement period (18711925), debt settlements were concluded comparatively quickly. The arrangements also contained some elements of debt release, especially with respect to reductions in the nominal value of outstanding bonds. However, debtor countries often had to pay for the liquidation of foreign bonds with a loss of their political and economic autonomy. Compared to the period 1871-1925, the efficacy of the crisis management declined somewhat during the third settlement period (1926-75), although the terms of the settlements were extremely favorable for debtor countries. Furthermore, substantial debt relief was not tied to political and economic control of debtor countries by their creditors.

\section{MULTILATERAL DEBT RESCHEDULING DURING}

THE POST-WAR ERA

After World War II, multilateral debt rescheduling became the single most important strategy to cope with debt crises. Rescheduling quite simply refers to the process of renegotiating the terms-particularly interest rates, maturities and grace periods - of a part of the credits falling due during a previously fixed time period (the consolidation period) or of credits already in arrears. In contrast to the strategies discussed above, multilateral reschedulings are usually applied before debtors have formally defaulted on their debts. By negotiating debt rescheduling agreements, creditors and debtors are able to maintain the impression of orderly financial relations. Thus, rescheduling has the significant advantage of preventing debt problems from becoming uncontrollable crises.

There are, however, some serious limitations to the rescheduling approach, some of which are discussed later in this section. Before this, we present a brief outline of the institutional features of debt rescheduling. Subsequently, we describe the development of rescheduling activity since World War II and then pass on to an analysis of data concerning the three dimensions of the efficacy of crisis management, political and economic influence on debtors, and the extent of debt relief provided by rescheduling operations. As in the previous section our empirical analysis aims at covering all the cases of rescheduling. ${ }^{23}$

The multilateral nature of the institutional framework of rescheduling must be qualified. Due to the segmentation of financing activities during the post-

23 The data used have been gathered from official sources (IMF, World Bank, OECD) as well as international financial press releases (Financial Times, Neue Zuercher Zeitung, Euromoney, Institutional Investor). They are fully discussed and evaluated in the appendices to Pfister and Suter (1986) and Stamm (1987). Unless otherwise indicated, all quantitative data presented in this section are taken from those two sources. 
war era-which is visible in the division of commercial, concessional (development), and trade finance among different actors of the financial system-it has not been possible to create a truly multilateral framework which includes all the creditors and borrowers simultaneously. Instead, individual debtors are confronted with specialized so-called creditor clubs of banks and official lenders, such as the development and trade financing agencies of core countries. Small private suppliers, on the other hand, have generally not been able to create similar frameworks and thus have remained largely dependent on the goodwill of debtors (International Monetary Fund, hereafter IMF, 1985:3439). Yet the establishment of the rescheduling mechanism has greatly profited from the structure of present-day international financial relations. Because the specialized creditor groups are quite homogeneous, comparatively small, and have a dense interaction structure which exposes some cooperative features even without debt problems, creditor cooperation has been easier to implement than during earlier crises (see introductory section).

In addition, multilateral development and financial institutions, such as the World Bank, the regional development banks and the International Monetary Fund, have not yet directly participated in debt reschedulings but have secured preferential treatment for themselves by stressing the special nature of their credits. They, however, have played a crucial role in promoting cooperation between creditors and debtors and maintaining debtor discipline by, for example, binding debt rescheduling agreements to the previous conclusion of standby agreements with the IMF. In addition, cofinancing arrangements with the World Bank and the occasional provision of bridging finance by central banks and the Bank for International Settlements have further enhanced cooperation and with this have strengthened the system's stability. Thus, the rescheduling strategy characterized by a complex field of interaction includes international financial institutions as the supervisors and strongly organized creditor clubs confronting debtors individually as the executors.

As illustrated below, creditor clubs usually only provide debtors with very limited debt relief on a case-by-case basis. Underlying this strategy has been the belief that it is important to keep borrowers on a short leash (Lipson 1981:622) to restore the capacity to make payments quickly - an assessment widely promoted by the Bretton Woods institutions. Consequently many debtors with chronic debt problems have had to undergo several reschedulings during the past years. In addition, different creditor groups were afraid of being played off against each other by debtors. Because official and private creditor clubs have never succeeded at establishing direct cooperation, a climate of mutual distrust often resulted in protracted negotiations. The difficulties of cooperation within creditor clubs at a lower structural level have also contributed to this outcome. Because those problems have been discussed elsewhere in some detail, we will only provide a very short overview here (see Suter et al. 1990). 
For official creditor clubs, most problems in creditor cooperation stem from the political and ideological differences of participating governments. Still, in most instances it was possible to implement a strategic consensus among creditors who usually not only have to cooperate in creditor clubs but also other international institutions, including the DAC and OECD. Most notable is the Paris Club, whose operations account for the bulk of the rescheduling agreements with official creditors of the past decade. Despite some conflicts about the best possible debt relief strategy and about some individual debtors, the Paris Club has generally been able to rally its members in relatively short time to interpret reschedulings as extraordinary short-term measures that should not be confused with development efforts (Cizauskas 1979:202; IMF 1981:22, 1985:20-25). This observation does not apply to all the other clubs of official creditors in operation during the post-war era. Political disputes on the treatment of Poland and Cuba for example, as well as their lack of membership in the IMF have delayed agreements for several months or even years in those cases. ${ }^{24}$ Still other official creditor clubs operating mainly during the 1970 s have provided more far-reaching rescheduling operations for either very poor or very important debtors by also considering developmental needs. ${ }^{25}$

Cooperation problems have been more accentuated among commercial banks. As there has often been a large number of banks involved (up to 1,000 ), so-called steering or advisory committees of about ten to twenty of the most important banks (usually the syndication leaders) were formed. The preliminary agreements negotiated by these committees often included, at the insistence of official creditors and the Bretton Woods institutions, the renewal of credits or even the provision of new money; and thus many banks found themselves in conflict with their principle of not throwing good money after bad. In addition, smaller and less exposed banks often speculated on being able to get out of their credit contracts at the cost of bigger institutes. Consequently, their resistance against signing debt relief agreements was considerable and could not always be broken by the more cooperative banks (IMF 1986:12; Padoan 1986:101 $f$, 131 $f$.). Thus, we find organizational problems somewhat similar to those faced by individual bondholders during earlier crises.

Still, commercial banks have also concluded a large number of rescheduling agreements during the past decade involving far larger amounts than the official renegotiations. Overall, the 226 rescheduling agreements concluded involved 52 countries and covered credits worth roughly $\$ 275$ billion between

24 Somewhat the same applies to the reschedulings of Ghana (1966-74) and Yugoslavia (1983 onwards).

25 This was the case in the recurrent debt reschedulings with India, Bangladesh, and Pakistan (largely during the 1970s) that took place within an aid consortium chaired by the World Bank. Strategic considerations applied to the reschedulings of Turkish debt by a group of OECD creditors $(1978-80)$. 
1956, when the first multilateral rescheduling agreement with Argentina was signed, and 1986 . Ninety agreements worth $\$ 204$ billion were negotiated by private creditors, ${ }^{26}$ as were ninety-nine worth $\$ 39$ billion by the Paris Club and thirty-seven worth $\$ 32$ billion by other groups of official creditors. Not surprisingly, only a minor proportion of agreements (56) was concluded before 1980 largely between official creditors (46) and involving some chronic problem borrowers (India, Argentina, Chile, Indonesia). In addition, seven of the ten bank reschedulings before 1980 were concluded in 1978 and 1979.

Yet, despite its importance, multilateral debt rescheduling is presently not the only form of crisis management. As noted in section I, the process of settlement of defaulted pre-war external debt has yet to be fully concluded and, in addition, some countries have repudiated their debts from the post-war era. ${ }^{27}$ Other countries with debt problems have undergone bilateral debt reschedulings, and some others received only short-term temporary deferments of debt repayments. ${ }^{28}$

\section{THE THREE DIMENSIONS OF DEBT CRISIS MANAGEMENT}

Let us now turn to a short discussion of the three dimensions of crisis management that have already been analyzed in the last section concerning the pattern of debt settlement prior to World War II.

\section{Efficacy of the Crisis Management}

Rescheduling as a means of settling debt problems undoubtedly seems very efficient, in terms of the time span for settlement from the onset of debt problems, at least at first sight. As noted above, reschedulings have usually been negotiated before formal debt suspensions by debtors occurred. Based on the discussion of the features of creditor clubs above, one would expect official creditors to be more efficient in concluding rescheduling agreements than private creditors. In fact, one unwritten principle of the Paris Club expects creditors and borrowers to conclude an agreement in principle within only two days of negotiations in Paris. This seems to have worked quite well in the past, but these meetings were usually preceded by an extensive phase of consultations involving creditor and debtor governments and the IMF.

26 One was negotiated with private suppliers (Nigeria 1984).

27 China 1949, Czechoslovakia 1959, Cuba 1963, Rhodesia 1965, North Korea 1974 (Suter 1990: Appendix A; Cline 1984:90).

28 Bilateral agreements have been concluded with Uruguay (1965), Egypt (1966), Yugoslavia (1965, 1971), Philippines (1970), Vietnam (1985), and Chile (on several occasions since 1985) (see Bittermann 1973:108-203; Dhonte 1975:183; Financial Times March 12, 1985; Stamm 1987), whereas temporary deferments were accorded to Zaire, Bolivia, Guyana during the late 1970 s and early 1980s (Stamm 1987:173). Note also that temporary deferments are usually agreed upon as a first emergency measure when a debtor runs into debt servicing problems. Those deferments are replaced by a formal rescheduling agreement. Thus, the renewal of deferments indicates that problems in negotiations caused a delay in, or the failure of, rescheduling efforts. 
Still, the hypothesis that official creditors were more efficient is also supported by data on the duration of renegotiations from the onset of debt problems (coded as the application of a debtor for a debt relief operation) and the conclusion of agreements. Although there are only data for forty-five agreements, the average duration can be tentatively estimated at about one year, with higher average values for private banks and lower ones for official lenders. However, this finding is bound to be misleading and not only for reasons of the small data base. For example, data on the conclusion of the bilateral agreements of Paris Club creditors are lacking, and consequently, an additional time span of several months between the negotiation of agreements in principle and their actual implementation must be added in some instances.

Even more important, reschedulings usually are not debt settlements in the true sense of the word but rather provisional solutions involving short-term delays of repayments. Many debtor countries had to conclude a series of reschedulings and even renew their older agreements repeatedly because they were unable to restore their solvency in the short time-frame provided by the creditors. More precisely, between 1976 and 1986 a total of forty-eight countries had to reschedule their external debt, but thirty-eight of them met more than once with their creditors. The median value for this period is three agreements per country, with the lead taken by Sudan with ten agreements, followed by Poland and Zaire (nine each) and Cuba and Madagascar (eight each). From this perspective, most of the debt settlements of the present crisis have been pending for several years. Thus, the speed of intervention must not be confounded with the very doubtful durability of the settlements reached.

\section{Creditors' Pressure on Debtor Countries}

Apart from some largely failed attempts, creditors have not exerted direct political or economic influence. ${ }^{29}$ Instead, they delegated this task to international financial institutions, particularly the IMF, whose adjustment programs indirectly reflect the preferences of the principal (official) creditors who are also the most influential members of the IMF. Consequently, the IMF has been identified as one of the central places of formulation of creditor interests and supports them further by coordinating creditor club actions and providing statistical materials on debtors. Thus, creditors have heavily relied on the IMF's operations and not surprisingly 77 percent of all reschedulings concluded until the end of 1986 were accompanied by IMF adjustment programs. The remaining agreements were concluded either with non-members of the IMF or countries that took an explicitly conflictive stance towards this organization. In both instances, the negotiations have on average been more

29 Those attempts include the failure of private banks to implement an economic adjustment program in Peru (for 1970s, see Cline 1981), the fruitless installation of an external financial supervisor in Zaire (for 1978, see Koerner et al. 1984:134-44) as well as the economic sanctions of creditors against Poland in the early 1980s (Stamm 1987:Appendix). 
protracted and the terms negotiated have tended to be harder. Despite the absence of direct and open influence by creditors, we thus find a great deal of indirect pressure exerted through international institutions that play an important role as policemen in the financial system (see Aronson 1985:141; Kahler 1986:265; and also Eichengreen and Portes 1989; Lipson 1989).

\section{The Degree of Debt Relief Granted by Creditors}

Because each debt settlement strategy has a different nature, we have to use somewhat different indicators than those employed in the previous section. This renders direct comparisons difficult. For example, interest arrears have seldom been rescheduled. Therefore, we are not able to construct a comparable indicator covering their capitalization (see Table 2). Somewhat the same applies to the previously used data on the reduction in outstanding debt, as it has tended to be renewed rather than reduced significantly during the post-war era. Yet, as in the previous section, we investigate the behaviour of interest rates and the extent of debt relief provided by reschedulings. The consolidation periods and the new maturities and grace periods are especially illustrative in this respect, and the actual amounts rescheduled, as well as the percentage of those amounts in relation to the total amount coming due during the consolidation period, give further useful indications as to the amount of debt relief and are thus provided.

All these data are presented in Table 3, grouped according to type of creditor and time of conclusion of the rescheduling agreement. The first column covers the precritical period before 1983, which is characterized by sporadic debt renegotiations with comparatively few chronic problem borrowers. The next two columns exhibit the data from the actual crisis. It was convenient to distinguish between the two-year periods in these two middle columns on the grounds that with the persistence of the crisis, debt rescheduling terms have been adjusted to the long-term nature of the crisis. For reasons of simplicity, we have omitted the data for official creditor clubs other than the Paris Club.

A clear general picture emerges from Table 3. Average amounts renegotiated have continually grown and the terms accorded to debtors have generally been very hard. Consolidation, grace periods, and maturities were relatively short, and on average 3 to over 15 percent of the rescheduled debt had to be paid as scheduled or as a down payment. ${ }^{30}$ Unfortunately, there are no data on the interest rates agreed upon by official creditors, but they seem to have been on a commercial basis as were the banks' interest rates (Hardy 1982:25f.; Lindert 1989:239-44). During the two years immediately following the onset of the debt crisis, banks negotiated higher rates than the original interest ( 2

\footnotetext{
30 Normally, only principal was renegotiated. Interest payments have only been capitalized on few occasions (Nicaragua 1980-85).
} 


\section{TABLE 3}

Average Terms of Reschedulings with the Paris Club and Commercial Banks, 1956-1986

\begin{tabular}{|c|c|c|c|c|}
\hline & $1956-82^{b}$ & $1983-84$ & $1985-86$ & $1956-86^{c}$ \\
\hline \multicolumn{5}{|l|}{ Amount $^{d}$} \\
\hline Paris Club & $266(37)$ & $412(27)$ & $532(33)$ & $397(97)$ \\
\hline Banks & 633 (22) & $1,642(34)$ & $4,782(27)$ & $2,404(83)$ \\
\hline \multicolumn{5}{|l|}{ Share $^{e}$} \\
\hline Paris Club & $83.6(28)$ & $91.6(16)$ & $91.4(21)$ & $88.1(65)$ \\
\hline Banks & $93.2(22)$ & $97.0(32)$ & $97.1(14)$ & $95.8(68)$ \\
\hline \multicolumn{5}{|c|}{$\begin{array}{c}\text { Consolidation } \\
\text { Period } f \\
\end{array}$} \\
\hline Paris Club & $23.1(37)$ & $13.5(26)$ & 20.1 (34) & $19.5(97)$ \\
\hline Banks & $17.6(16)$ & $20.9(29)$ & $38.5(26)$ & $26.6(71)$ \\
\hline \multicolumn{5}{|l|}{ Maturity ${ }^{g}$} \\
\hline Paris Club & $9.9(36)$ & $9.9(23)$ & $9.8(24)$ & $9.9(83)$ \\
\hline Banks & $6.5(22)$ & $7.1(34)$ & $9.6(22)$ & $7.6(78)$ \\
\hline \multicolumn{5}{|l|}{ Grace $^{n}$} \\
\hline Paris Club & $3.8(29)$ & $4.7(16)$ & $4.8(24)$ & $4.3(69)$ \\
\hline Banks & $3.1(20)$ & $3.0(32)$ & $3.6(21)$ & $3.2(73)$ \\
\hline \multicolumn{5}{|l|}{ Interest $^{i}$} \\
\hline$\overline{\text { Banks }}$ & $1.65(21)$ & $1.94(33)$ & $1.47(22)$ & $1.73(76)$ \\
\hline
\end{tabular}

a The numbers in the parentheses indicate the number of cases used in the calculations.

${ }^{b}$ The time period of banks begins only in 1978 , so the three agreements concluded before that year are omitted in these calculations.

cThe omission described in note $b$ also affects the figures in this column.

$d$ The amount is in millions of dollars.

- The share is the percentage share of rescheduled credits in proportion to the total amount falling due.

$f$ The consolidation period is in terms of months.

s Maturity indicates the time after which the whole principal must be paid back and includes the grace period.

${ }^{h}$ This is the grace period, or the time in which only interest payments are due.

iThe interest category refers to the interest rate and is indicated as a percentage over the London Interbank Offered Rate. There are no data on the interest rates accorded by official creditors. SourCes: Pfister and Suter (1986:Appendix); Stamm (1987:Appendix).

percent over the London Interbank Offered Rate (LIBOR) on average) and on several occasions exacted so-called rescheduling fees of around 1 percent of the total amount renegotiated. In sum, reschedulings have largely been concluded on commercial terms involving only small long-term debt relief. 
Several qualifications are in order. Most indicators have improved significantly during the 1985-86 period, and this trend has continued during the following years. The Paris Club, for its part, has recently deviated from its standard practice of providing debtors with consolidation periods of only one year, maturities of ten years, and grace periods of five years. Although this rule still applies to the larger debtors, poor debtors have often been provided with twenty-five-year maturities and ten-year grace periods; and in some instances consolidation periods of several years were included in the same agreement. In addition, some creditors have unilaterally converted some of their loans into grants on special occasions (IMF 1988:12).

This trend towards better terms for debtors has even been more pronounced for commercial banks. As can be seen from Table 3, during the 1985-86 period interest rates dropped by almost half a percent (from an average of 1.94 percent to 1.47 percent over LIBOR) and consolidation periods have almost doubled to an average of more than three years (38.5 months). At the same time, maturities have on average lengthened by 2.5 years and grace periods, too, improved, although by a lesser amount of only about half a year. From 1987 onwards this trend was consolidated. Interest rates have dropped to an average of under 1 percent over LIBOR, rescheduling fees have been left totally aside, and the other terms have also improved again. In addition, a large proportion of agreements also included the provision of new money and the maintenance of short-term credit.

To sum up, the rescheduling strategy can be characterized as follows. First, the settlement of debt problems is quick but rather provisional. Second, creditors do not exert any direct influence on debtors, but indirect, largely economic, pressure is applied by international organizations, notably the IMF. Third, there has not been debt forgiveness on a large scale.

\section{EXPLAINING THE PATTERN OF DEBT SETTLEMENT}

In the two previous sections we have described the patterns of debt settlements of defaulted foreign bonds predominant prior to World War II on the one hand and multilateral reschedulings of external debt in the post-war era on the other. Our empirical analysis has revealed marked differences between these two debt settlement regimes with respect to the efficacy of the crisis management, the degree of debt relief, and the degree of political and economic pressures exerted on debtor countries by creditors.

The first and most obvious difference refers to the efficacy of the debt settlement. In the case of multilateral reschedulings, crisis management is able to respond much more quickly. Although agreements between bondholders and debtor countries concerning the settlement of defaulted bonds could be reached only after six to fourteen years, multilateral reschedulings were generally concluded within just one year. Conversely, the durability of 
debt settlements is considerably higher in the case of default settlements. The fact that debt reschedulings usually provide only provisional settlements hints at the existence of a trade-off between speed of intervention and durability of solutions.

Second, debtor countries obtained much more favorable terms for debt settlements for defaulted foreign bonds than for multilateral reschedulings. Several empirical studies dealing with the interwar period already showed that the settlement of the crisis of the 1930s brought debtor countries substantial debt relief (Eichengreen and Portes 1989; Jorgensen and Sachs 1989). Our findings demonstrate that this argument can be generalized to all settlements of bond default during the nineteenth and twentieth centuries. Moreover, the quantitative nature of our indicators allows us to make a more precise assessment of real debt relief. Thus, our empirical analysis suggests that on the average the settlement of defaulted foreign bonds comprised a reduction of outstanding debts (including arrears of interest) of about 30 percent. As much as an estimated 50 percent of outstanding debts (including arrears of interest) was liquidated through the debt settlements in the crisis of the 1930s. In addition, interest rates on these reduced debts were lowered by more than onethird. This substantial debt release is in marked contrast with the hitherto hard terms of rescheduling agreements during the first years of the debt crisis of the 1980 s.

Third, one may conclude that creditors exerted open political and economic pressures on debtor countries in only a few cases involving settlements of defaulted foreign bonds. By contrast, creditors exerted substantial but indirect economic pressure in multilateral reschedulings due to IMF adjustment programs imposed on debtor countries. Our empirical analysis has shown that the majority of reschedulings has been tied to such adjustment programs (see also Eichengreen and Lindert 1989). Basically, this finding is in accordance with Lipson's (1989) hypothesis of more interventionist policies during the United States' hegemony than during British supremacy. Yet, Lipson deals only with political pressures and sets aside the more important economic control exerted by creditors.

These three regularities are closely associated. Thus, the quick and efficient intervention of creditors, together with their capacity to exert pressures on debtor countries to carry out adjustment programs, prevented any substantial debt relief in the present debt crisis. In accordance with our basic hypothesis from the introductory section of this article, these three regularities resulted from the increasing institutionalization of creditors' cooperation during the post-war era, which was made possible by the marked concentration of international lending amongst relatively few actors.

Our analysis of the actor structure and the institutional framework of the debt settlement processes prior to World War II has clearly shown the low degree of creditor cooperation. The large number of dispersed individual 
bondholders made organizing these creditors virtually impossible. Consequently, they were neither capable of responding quickly to adverse developments nor of protecting their interests against borrowers. This explains the low efficacy of debt management, the favorable terms of settlements for debtor countries, and the failure of creditors to enforce political and economic control upon debtors.

After World War II the actor structure on the creditors' side substantially changed: Nation-states, international organizations, and large bank syndicates began to prevail instead of individual bondholders. This process implied a substantial reduction in the number of actors, allowing for a dense interaction structure. From this starting point, it was comparatively easy to organize creditor interests in the instances of debt problems and, as those problems grew in number, to institutionalize such creditor clubs as the Paris Club which had clearly defined structures and aims. Yet the particular features of official and private lending resulted in differences in the organization and efficacy of different creditor clubs. The comparative strength of the official creditor clubs was partly due to the fact that the principal official lenders are also the most important decision-making units in the international organizations, mainly the IMF. These organizations could readily be used as promoters and supervisors of debt and adjustment strategies. Thus, the institutionalization of creditor clubs involved an effective linkage of debt management and economic influence on adjustment. The political and social consequence of these austerity policies is the massive and unprecedented protest by social movements in debtor countries (see Walton and Ragin 1990).

In addition to this basic change in the debt settlement regime from defaults to rescheduling, three further, though less important, differences in the crisis management of the three earlier settlement periods (1821-70, 1871-1925, and 1926-75) have been demonstrated which have not yet been discussed in the literature. First, the efficacy of debt settlements was highest during the period 1871-1925. Second, economic and political control of debtor countries by creditors was most pronounced during the period 1871-1925. Third, there is a trend towards a higher degree of debt relief, with the most favorable terms granted to debtors during the settlement period 1926-75. These differences are in general consistent with our sub-hypotheses drawn from the concept of world leadership cycles. Although this concept is yet somewhat vague and requires more theoretical specification (see Lipson 1989 for an alternative explanation), our empirical analysis suggests its relevance for the explanation of differences in the patterns of debt settlement. This may also be demonstrated with respect to two aspects of the present debt crisis management. First, the change within the actor structure on the creditors' side, which we regard as the basic prerequisite for the institutionalization of creditor clubs, occurred when the United States shaped the new economic and political world order during and after World War II. Thus, the World Bank, the IMF, 
and the OECD were all established under the leadership of the United States and initially served as important organizational pillars of the hegemony of the United States, becoming the institutional core of rising creditor cooperation during the post-war era. Second, the provisional nature of the current rescheduling approach, together with the unfavorable terms for debtors, may well be related to the decline of United States hegemony since the 1970s.

\section{LOOKING AHEAD: PROSPECTS FOR FUTURE DEBT}

\section{SETTLEMENTS}

Our analysis shows that, compared to the settlement of defaulted foreign governmental bonds, the present settlement strategy of multilateral rescheduling is much more efficient because it is faster in intervening, although it mainly deals with short-term symptoms on a provisional basis. This raises the question about the future of the rescheduling strategy and the prospects for a long-term solution of the present crisis. In this final section the different debt proposals suggesting ways out of the present debt crisis are discussed in the light of the historical experiences from settlements of earlier debt crises.

During the 1980 s numerous plans and debt proposals were made. For instance Bergsten et al. (1985) alone discuss twenty-four specific alternatives for private bank debts. Although there was a surge of innovative new schemes in the very beginning of the debt crisis, the realized rescheduling approach was generally considered as more or less successful and the discussion of more far-reaching solutions became less lively towards the mid-1980s. ${ }^{31}$ It is indicative of the state of the debt crisis management in the final years of that decade that the debt proposal discussion revived a focus on more long-term solutions (see Bird 1987; Pastor 1987; Feinberg and Ffrench-Davis 1988; Dornbusch 1989; Griffith-Jones 1989; O'Neill 1989; and the Journal of Economic Perspective 1990). We do not intend to give a detailed overview on the various debt proposals here. Rather, the following discussion will be confined to the four basic schemes to which most debt proposals may be attributed (compare Suter et al. 1988:38). These ideal-typical scenarios may be characterized as the scenarios of debt repudiation, debt release, debt repayment, and debt increase.

First, debt repudiation aims at reducing debt burden by liquidating a substantial part of indebtedness. Debt repudiations are declared unilaterally by debtor countries without the creditor's consent and thus represent a violation of contractual obligations. As discussed in detail in the previous sections, debt repudiation was the usual strategy before World War II. Debt repudiation, which has hitherto always been made by individual borrowing countries sepa-

31 This may be illustrated by the rhetorical question, "Debt: Are We at the End of the Crisis?" raised by Michel Camdessus (1986), managing director of the IMF and former chair of the Paris Club. 
rately, can also be declared jointly by the most heavily indebted countries coordinating their policies in a debtor's cartel (see Kaletsky 1985; Hojman 1987; Holler 1989).

Second, like debt repudiation, debt release intends to reduce a substantial part of outstanding debt. Yet, contrary to debt repudiation, this reduction is achieved by the joint actions of debtors and creditors. Debt release implies that commercial banks allow substantial write-offs for losses and that the governments of the creditor countries absorb these losses. One of the most paradigmatic versions of this scenario has been advanced by the German economist, Wilhelm Hankel (1984:90-93). Debtor countries and their political leaders of course support debt release. Fidel Castro (1985), for instance, proposed that creditor countries could liquidate outstanding debts by reducing military expenditures by 12 percent. Elements of debt release are also included in the debt discounting proposals suggested by prominent bankers and economists, who recommend that banks transfer frozen assets to existing or newly established international organizations (see Kenen 1983, 1990; Sachs 1990).

Third, under debt repayment, debtors have to meet their obligations in full. This means that the debtor countries have to earn foreign exchange by producing export surpluses either by increasing exports or by reducing imports. An alternative way for debtor countries to earn foreign exchange is to sell parts of their property (such as state-owned companies) to foreigners. The consequences of such schemes are privatization and denationalization of debtors' economies.

The fourth scenario, debt increase, is based on a global Keynesian model. Advocates of this proposal, like the Brandt Commission (1980, 1983), recommend a massive increase of financial flows to developing countries to free frozen assets and overcome economic recession. As in the case of debt release this proposal intends to strengthen international financial institutions. The required financial resources may be raised by increasing real transfers from developed countries (such as increasing official aid, taxing international trade or arms production) or by creating international liquidity (such as increasing the Special Drawing Rights (SDRs) of the IMF). Insofar as the latter strategy is carried out, this scheme may be called debt inflationing.

Debt settlement patterns of the earlier debt crises contained elements of all four of these ideal-typical scenarios. Thus, an unilateral suspension of debt service payments at least for some years was common practice, although a permanent debt repudiation rarely happened. Our empirical material has shown that the bondholder's representatives granted partial debt release during all the debt crises before World War II. Debt repayment, of course, also occurred, among others in the form of cession of property rights to creditors. However, compared to the other three scenarios, there were-apart from the capitalization of arrears of interest payments-only a few instances of debt 
increase before World War II. Obviously, it proved rather difficult to convince individual bondholders to invest fresh money in the virtually insolvent debtor countries. ${ }^{32}$

Although historical evidence for all of the four ideal-typical scenarios may be found, the models actually realized in the wake of the past debt crises always were a combination of them. Specifically, one may discern a certain temporal sequence in the occurrence of the four basic scenarios. Thus, during the initial stages of an impending debt crisis, debtor countries usually tried to mobilize new loans on capital markets (debt increase). If this proved impossible, they were forced to take some adjustment measures (debt repayment) or to suspend debt service payments (debt repudiation). The settlements eventually negotiated between debtor countries and creditors after a period of default usually contained some debt relief, such as reductions in interest rates or outstanding debts (debt release) and elements of debt repayment.

The above reasoning suggests that the question about the prospect of future debt settlements is not a matter of pure debt repayment, debt increase, debt repudiation, or debt release but rather of combining elements from different basic scenarios. As discussed in detail in the previous sections, the strategy of multilateral rescheduling applied to the present debt crisis differs substantially from the settlement pattern of past crises. In terms of the four basic scenarios, the rescheduling approach may be characterized as a combination of debt repayment (partly postponed to the future) and debt increase (as far as new credits were extended and interest payments were capitalized) - a model that was very exceptional before World War II. Moreover, our analysis of developments within the rescheduling culture since the onset of the present debt crisis suggests changes in the combination and importance of the different basic scenarios. Thus, during the first two years, elements of debt repayment clearly prevailed. The Baker Plan proposed in 1985 recommended strengthening international institutions, massively expanding the disbursements of new credits by the World Bank (an increase of 50 percent for 1986-88) and by private banks ( $\$ 20$ billion for fifteen heavily indebted countries for three years), and shifting the structural adjustment processes of debtor countries from debt repayment to debt increase. Yet, in reality the Baker Plan never became effective because the private banks completely failed to mobilize the required amount of fresh money (see Pastor 1987).

During the second half of the 1980s new debt relief techniques were imple-

32 One of these few instances was the consolidation of the Moroccan external debt in 1904 by a consortium of French banks. This transaction was, however, strongly supported by the French foreign ministry in order to secure French control on the Moroccan state against the interests of other imperial powers (see Guillen 1972). Another prominent case of debt increase was the Argentine debt settlement after the crisis of 1890 . As a result of a series of debt conversions and capitalization of interest payments, foreign debt of the Argentine government rose from 204 billion gold pesos to 389 billion (Marichal 1989:159-66). 
mented, indicating a gradual shift from the combination of debt repayment and debt increase to debt repayment and debt release. Three measures of techniques of debt release have been of special importance. First, a secondary market of third world debt evolved where debts were traded at discounts ranging from 20 to 90 percent. Second, several rescheduling agreements included the possibility of debt-to-equity swaps. In such swap transactions investors buy debt at a discount from the banks and receive the countervalue of the credits as investment capital or shares in existing local firms in the debtor countries (see Parhizgari 1988). The recently initiated debt for nature swaps refer to the same basic idea: A conservation organization acquires debt titles at a certain discount, converts them into local currency, and then uses the proceeds to finance conservation programs in the country concerned (Hansen 1989). Third, official creditors at the Toronto summit of the seven major industrial countries in 1988 decided to grant debt relief to the heavily indebted low-income countries, particularly those in sub-Saharan Africa. The recommended techniques included concessional interest rates, longer repayment periods, and partial write-offs of debt service obligations.

The Brady Plan adopted in 1989 extended this debt reduction strategy to the heavily indebted middle-income countries on the one hand and to international private banks on the other (see Frenkel 1989). It represents, therefore, a further and more decisive step towards the scenario of debt release. Under the Brady Plan, private creditors can choose among three options: reducing outstanding debt or in interest rates, or granting new loans. As in the case of the Baker Plan the Bretton Woods institutions are to play an important role in the new debt strategy by financing or guaranteeing debt reduction (see IMF 1989; Sachs 1989). The Mexican rescheduling of early 1990, which served as a test case of the Brady Plan, illustrates, however, the as yet limited nature of this debt release. This agreement, which covered external debts of $\$ 48$ billion owed to some 500 private banks, brought the Mexican government a reduction of $\$ 1.7$ billion in interest payments (corresponding to 10 percent of the total debt service due) and a reduction of $\$ 6.7$ billion in outstanding debts (amounting to 7 percent of total outstanding debt). Only 10 percent of all the banks involved agreed to offer new loans, indicating, thereby, their lack of support for the scenario using debt increase. Compared to the settlements of defaulted foreign governmental bonds, in which 40 percent of arrears of interest were cancelled and outstanding debts and interest rates were reduced by an average of about 20 percent, the degree of debt release granted to Mexico by the Brady Plan rescheduling has to be judged as rather low.

In sum, the developments in the strategies for debt settlement during the past decade show a shift away from pure debt repayment. In the middle of the 1980s, an attempt to combine debt repayment and debt increase largely failed, facilitating, thereby, a movement towards the scenario of debt release at the 
end of the decade. Yet historical evidence suggests that the elements of debt release have to be considerably strengthened in future, particularly if the feasibility of debt increase further deteriorates.

\section{REFERENCES}

Aggarwal, Vinod K. 1989. "Interpreting the History of Mexico's External Debt Crises," in Barry Eichengreen and Peter $\mathbf{H}$. Lindert, eds., The International Debt Crisis in Historical Perspective, 140-188. Cambridge, Mass.: MIT.

Aronson, Jonathan David. 1985. "Muddling Through the Debt Decade," in W. Ladd Hollist and F. LaMond Tullis, eds., An International Political Economy (International Political Economy Yearbook, Vol. 1), 127-151. Boulder, Colo.: Westview Press. Association Belge (Association Belge pour la Defense des Détenteurs de Fonds Publics). Rapports. 1949-75. Anvers: Association Belge.

Association Français (Association Nationale des Porteurs Français de Valeurs Mobiliers). Rapports. 1950-75. Paris: Association Nationale.

Bazant, Jan. 1968. Historia de la Deuda Exterior de México 1823-1946. México: El Colegio de México.

Bergsten, C. Fred; William R. Cline; and John Williamson. 1985. Bank Lending to Developing Countries. The Policy Alternatives. Washington D.C.: Institute for International Economics.

Bird, Graham. 1987. "Interest Rate Compensation and Debt: Would a Cap Fit?" World Development, 15:9, 1237-42.

Bittermann, Henry. 1973. The Refunding of International Debt. Durham, N.C.: Duke University Press.

Borchardt, Edwin. 1951. State Insolvency and Foreign Bondholders, vol. I of General Principles. New Haven, Conn.: Yale University Press.

Born, Karl Erich. 1986. "Erfahrungen aus internationalen Finanzkrisen der Vergangenheit," in Armin Gutowski, ed., Die internationale Schuldenkrise, 9-29. Berlin: Duncker and Humblot.

Brandt Commission (Independent Commission on International Development Issues). 1980. North-South: A Programme for Survival. London: Pan.

1983. Common Crisis, North-South: Cooperation for World Recovery. London: Pan.

Buckley, Walter. 1967. Sociology and Modern Systems Theory. Englewood Cliffs, N.J.: Prentice Hall.

Camdessus, Michel. 1986. "Debt: Are We at the End of the Crisis?" European Economic Review, 30:469-75.

Cardoso, Eliana A.; and Rudiger Dornbusch. 1989. "Brazilian Debt Crises: Past and Present," in Barry Eichengreen and Peter H. Lindert, eds., The International Debt Crisis in Historical Perspective, 106-139. Cambridge, Mass.: MIT.

Castro, Fidel. 1985. Nada podrá detener la marcha de la historia. Texto integro de la entrevista concedida por Fidel Castro al académico Jeffrey Elliot y al congresista Mervyn Dymally. La Habanna: Ed. Politica.

Chase-Dunn, Christopher. 1989. Global Formation: Structures of the World-Economy. Cambridge and Oxford: Basil Blackwell.

Cizauskas, Albert C. 1979. "International Debt Renegotiation: Lessons from the Past." World Development, 7:2, 199-210.

Cline, William R. 1981. "Economic Stabilization in Peru, 1975-78," in William R. Cline and Sidney Weintraub, eds., Economic Stabilization in Developing Countries, 297-334. Washington, D.C.: Brookings Institution. 
1984. International Debt: Systemic Risk and Policy Response. Washington, D.C.: Institute for International Economics.

Corporation of Foreign Bondholders (CFB). Annual Reports of the Council, 18731985. London: Corporation of Foreign Bondholders.

Dhonte, Pierre. 1975. "Describing External Debt Situation: A Roll-Over Approach." IMF Staff Papers, 22:159-86.

Dornbusch, Rudiger. 1989. “The Latin American Debt Problem: Anatomy and Solutions," in Barbara Stallings and Robert Kaufman, eds., Debt and Democracy in Latin America, 7-22, Boulder, Colo.: Westview.

Eichengreen, Barry; and Peter H. Lindert, eds. 1989. The International Debt Crisis in Historical Perspective. Cambridge, Mass.: MIT.

Eichengreen, Barry; and Richard Portes. 1986. "Debt and Default in the 1930s: Causes and Consequences." European Economic Review, 30:599-640.

- 1989. "After the Deluge: Default, Negotiation, and Readjustment during the Interwar Years," in Barry Eichengreen and Peter H. Lindert, eds., The International Debt Crisis in Historical Perspective, 12-47. Cambridge, Mass.: MIT.

Feinberg, Richard E.; and Ricardo Ffrench-Davis, eds. 1988. Development and External Debt in Latin America. Notre Dame, Ind.: University of Notre Dame Press.

Feis, Herbert. 1930. Europe: The World's Banker 1870-1914. New Haven: Yale University Press.

Fishlow, Albert. 1986. "Lessons From the Past: Capital Markets During the 19th Century and the Interwar Period," in Miles Kahler, ed., The Politics of International Debt, 37-93. Ithaca, N.Y.: Cornell University Press.

—. 1989. "Conditionality and Willingness to Pay: Some Parallels from the 1890s," in Barry Eichengreen and Peter H. Lindert, eds., The International Debt Crisis in Historical Perspective, 86-105. Cambridge, Mass.: MIT.

Frenkel, M. (1989). "The International Debt Problem: An Analysis of the Brady Plan." Intereconomics, May/June, 110-116.

Griffith-Jones, S. 1989. "Options for Dealing with the Debt Problem of MiddleIncome Countries." European Journal of Development Research 1:2, 97-108.

Guillen, Pierre. 1972. Les Emprunts Marocains 1902-1904. Paris: Edition Richelieu.

Hankel, Wilhelm. 1984. Gegenkurs: Von der Schuldenkrise zur Vollbeschäftigung. Berlin: Siedler.

Hansen, S. 1989. "Debt for Nature Swaps." Ecological Economics, 1:275-88.

Hardy, Chandra S. 1982. Rescheduling Developing-Country Debts, 1956-1981: Lessons and Recommendations (Monograph/Overseas Development Council, No. 15). Washington, D.C.

Hojman, David. 1987. "Why the Latin American Countries Will Never Form a Debtors' Cartel." Kyklos, 40:2, 198-218.

Holler, Manfred. 1989. "Why the Latin American Countries Do Not Form a Debtors' Cartel." Kyklos, 42:1, 89-102.

IMF. 1981. External Indebtedness of Developing Countries (Occasional Paper 3). Washington, D.C.: IMF.

- 1985. Recent Developments in External Debt Restructurations (Occasional Paper 40). Washington, D.C.: IMF.

- 1986. International Capital Markets: Developments and Prospects (Occasional Paper 43). Washington, D.C.: IMF.

- 1988. Multilateral Official Debt Rescheduling: Recent Experience (World Economic and Financial Survey, May 1988). Washington, D.C.: IMF.

. Survey, 18:12 (June 12). Washington, D.C.: IMF. 
Jorgensen, Erika; and Jeoffrey Sachs. 1989. "Default and Renegotiation of Latin American Foreign Bonds in the Interwar Period," in Barry Eichengreen and Peter H. Lindert, eds., The International Debt Crisis in Historical Perspective, 48-85. Cambridge, Mass.: MIT.

Kahler, Miles, ed. 1986. The Politics of International Debt. Ithaca, N.Y.: Cornell University Press.

Kaletsky, Anatole. 1985. The Costs of Default. New York: Twentieth Century Fund. Kenen, Peter. 1983. "A Bailout Plan for the Banks." The New York Times, March 6. . (1990). "Organizing Debt Relief: The Need for a New Institution." Journal of Economic Perspectives, 4:1, 7-18.

Kennedy, Paul. 1987. The Rise and Fall of the Great Powers. New York: Random House.

Kindleberger, Charles Poor. 1973. The World in Depression 1929-1939. Berkeley: University of California Press.

Macmillan.

Koerner, Peter; Gero Mass; Thomas Siebold; and Rainer Tetzlaff. 1984. Im Teufelskreis der Verschuldung: Der Internationale Währungsfonds und die Dritte Welt. Hamburg: Junius.

Landes, David S. 1958. Bankers and Pashas: International Finance and Economic Imperialism in Egypt. London: William Heinemann.

Lindert, Peter H. 1989. "Response to Debt Crisis: What is Different about the 1980s?" in Barry Eichengreen and Peter H. Lindert, eds., The International Debt Crisis in Historical Perspective, 227-75. Cambridge, Mass.: MIT.

Lipson, Charles. 1981. "The International Organization of Third World Debt." International Organization, 35:4, 603-31.

1985. Standing Guard: Protecting Foreign Capital in the Nineteenth and Twentieth Centuries. Berkeley: University of California Press.

- 1989. "International Debt and National Security: Comparing Victorian Britain and Postwar America," in Barry Eichengreen and Peter H. Lindert, eds., The International Debt Crisis in Historical Perspective, 189-226. Cambridge, Mass.: MIT.

Marichal, Carlos. 1989. A Century of Debt Crises in Latin America: From Independence to the Great Depression, 1820-1930. Princeton, N.J.: Princeton University Press.

Modelski, George. 1978. "The Long Cycle of Global Politics and the Nation State." Comparative Studies in Society and History, 20:2, 214-35.

O'Neill, Helen, ed. 1989. "Third World Debt: How Sustainable are Current Strategies and Solutions?" European Journal of Development Research, 1:2.

Padoan, Pier Carlo. 1986. The Political Economy of International Financial Instability. London: Croom Helm.

Pamuk, Sevket. 1987. The Ottoman Empire and European Capitalism 1820-1913: Trade, Investment and Production. Cambridge: Cambridge University Press.

Parhizgari, Ali M. 1988. "Debt Swaps: Innovative Proposals." Economic Impact, 2:42-46.

Pastor, Robert A., ed. 1987. Latin America's Debt Crisis: Adjusting to the Past or Planning for the Future? Boulder, Colo.: Lynne Rienner.

Pfister, Ulrich; and Christian Suter. 1986. Verschuldung im Weltsystem: Eine systemtheoretische Analyse der internationalen Finanzbeziehungen. Schlussbericht zum Nationalfondsprojekt, "Zu Struktur und Wandel des Weltsystems seit 1960" 
(Gesuchnummer 1.060-0.84). Zürich: Soziologisches Institut der Universität Zürich.

1987. "International Financial Relations as Part of the World-System." International Studies Quarterly, 31:3, 239-72.

Radke, Johannes; and Peter Sauer. 1980. "The Influence of the Colonial Powers in Liberia Before the First World War," in Eckhard Hinzen and Robert Kappel, eds., Dependence, Underdevelopment and Persistent Conflict-On the Political Economy of Liberia (Veröffentlichungen aus dem Übersee-Museum Bremen, Series F, Vol. 11). Bremen: Übersee-Museum.

Sachs, Jeffrey D. 1989. "Making the Brady Plan Work." Foreign Affairs, 68:87-104. - 1990. "A Strategy for Efficient Debt Reduction." Journal of Economic Perspectives, 4:1, 19-29.

Scheetz, Thomas. 1986. Peru and the International Monetary Fund. Pittsburgh, Pa.: University of Pittsburgh Press.

Stallings, Barbara. 1987. Banker to the Third World: U.S. Portfolio Investment in Latin America, 1900-1986. Berkeley: University of California Press.

Stamm, Hanspeter. 1987. Kooperation und Konflikt im Weltfinanzsystem: Eine Analyse multilateraler Umschuldungsaktionen seit 1956 (Unpublished Thesis). Zurich: Sociological Institute, University of Zurich.

Suter, Christian. 1989. "Long Waves in Core-Periphery Relationships within the International Financial System: Debt-Default Cycles of Sovereign Borrowers." $R e$ view, 12:1, 1-49.

-1990. Schuldenzyklen in der Dritten Welt: Kreditaufnahme, Zahlungskrisen und Schuldenregelungen peripherer Länder im Weltsystem von 1820 bis 1986 (Doctoral Dissertation, University of Zurich). Frankfurt: Anton Hain. English edition forthcoming as Debt Cycles in the World Economy. Boulder, Colo.: Westview.

Suter, Christian; Ulrich Pfister; and Volker Bornschier. 1988. "International Financing in the 1980's: A World-System Perspective," in H. W. Singer, Neelambar Hatti, and Rameshwar Tandon, eds., Resource Transfer and Debt Trap, P. 1, 20-59 (New World Order Series 5). New Delhi: Ashish.

Suter, Christian; Hanspeter Stamm; and Ulrich Pfister. 1990. "External Public Debt of the Periphery: A Recurrent Problem of World Society," in Volker Bornschier and Peter Lengyel, eds., World Society Studies, Vol. 1, 250-84. New York: Campus.

Thobie, Jacques. 1980. "Finance et Politique Exterieure: 1'Administration de la Dette Publique Ottomane 1881-1914," in Osman Okyar and Halil Inalcik, eds., Social and Economic History of Turkey (1071-1920), 311-22. Ankara: Meteksan.

Union des Porteurs Français de Rentes Portugaises. 1893. Réunion plénière des Créanciers de la dette extérieure portugaise du 20 Juin 1893 à l'Hotel Continental Paris. Paris.

Voss, Thomas. 1985. Rationale Akteure und soziale Institutionen. Munich: Oldenbourg.

Wallerstein, Immanuel. 1983. "The Three Instances of Hegemony in the History of the Capitalist World-Economy." International Journal of Comparative Sociology, $24: 1-2,100-8$.

Walton, John; and Charles Ragin. 1990. "Global and National Sources of Political Protest: Third World Responses to the Debt Crisis." American Sociological Review, 55:6, 876-90.

White, E. N. 1986. "Latin America's Debt Crisis of the 1930s: Lessons for the 1980s, in Iván Berend and Knut Borchardt, eds., The Impact of the Depression of the 1930's and its Relevance for the Contemporary World (Comparative Studies Pre- 


\section{CHRISTIAN SUTER AND HANSPETER STAMM}

pared for the A/5 Session of the Ninth International Economic History Congress, 24-29 August, 1986, Bern Switzerland), 484-96. Budapest: Karl Marx University of Economics.

Winkler, Max. 1933. Foreign Bonds: An Autopsy. Philadelphia: Roland Swain.

Wynne, William H. 1951. State Insolvency and Foreign Bondholders, Vol. II of Selected Case Histories of Governmental Foreign Bond Defaults and Debt Readjustments. New Haven, Conn.: Yale University Press. 